\title{
Board of Directors and Capital Structure: Evidence from Leading Malaysian Companies
}

\author{
Teh Boon Heng \& Shabnam Azrbaijani \\ Faculty of Management, Multimedia University Malaysia, Malaysia \\ Ong Tze San (Corresponding author) \\ Department of Accounting and Finance, Faculty of Economics and Management \\ Universiti Putra Malaysia, 43400 UPM Serdang, Selangor, Malaysia \\ E-mail: tzesan@econ.upm.edu.my
}

Received: August 4, 2011

doi:10.5539/ass.v8n3p123
Accepted: November 24, $2011 \quad$ Published: March 1, 2012

URL: http://dx.doi.org/10.5539/ass.v8n3p123

\begin{abstract}
Malaysia is one of the rapidly developing economies in South-East Asia which embraces the concept of good corporate governance due to the 1997-1998 Asian financial crises. This study investigates the relationship between board of directors and company's capital structure in an emerging market, Malaysia. This research paper covers 75 non-financial leading Malaysian companies, which are employed as a price index, listed on Kuala Lumpur stock exchange (KLSE) from the year 2005 to 2008 fiscal years. A multiple regression analysis has been used to examine the linkage between board of director's features and capital structure decisions of the listed companies. Measures of board of directors employed are size of the board, presence of non-executive directors on the board, presence of independent non-executive directors on the board and CEO/Chair duality. Results reveal that board size and presence of independent non-executive directors on the board have significant, negatively and positively correlation with debt to asset ratio respectively. However corporate capital structure decisions are not found significantly influenced by $\mathrm{CEO} /$ Chair duality and the presence of non-executive directors on the board. Consequently based on the results, board of director's features such as board size and presence of independent non-executive directors on the board play an important role in determination of financial mix of the companies.
\end{abstract}

Keywords: Corporate governance, Board of directors, Non-executive directors, CEO duality, Capital structure, Malaysia

\section{Introduction}

The significance of choosing the best financing decision among the available alternatives is undeniable for the financial well-being of a firm. Capital structure decision that has to be made by finance managers is one of the three financing decisions including investment, financing and dividend decisions. The optimal choice of capital structure at diverse situations among the other existing investment opportunities, which can gain the highest rate of return and the lowest cost are strongly related to firm's capability to fulfill the requests of its various stakeholders. This reality highlights the importance of capital structure decisions which are mentioned above. According to Abor and Biekpe (2005), capital structure decision is essential due to the necessity of maximizing returns to numerous organizational stakeholders and also the effect of this decision on an organization's capability to deal with its competitors.

Financial distress which can eventually lead to bankruptcy is the consequence of the false decisions about the capital structure of the company. Thus, finance managers should set the capital structure in a way to enhance the company's value along with consideration the preferences of the corporation's shareholders. In fact, based on agency cost theory, managers tend to execute in their own best interest instead of the best interest of shareholders. These agency problems existed because of the resolution between the two important mechanisms of the corporations including ownership and control of the firm. This matter highlights the necessity of effective corporate governance with an independent board in every organization in order to alleviate the agency issues. 
Board of directors consists of individuals who are nominated by the company's shareholders in order to oversee the firm and its management. Consequently, having a good independent board is important to achieve strong company performance and subsequently increase in stock value. According to Saad (2010), board of directors is considered as one of the major 2 components of the corporate governance which provides an efficient regulatory and controlling mechanism to decrease the agency problems. Therefore, there are additional provisions to the shareholders and other investors.

Corporate governance refers to the practices implemented to run and regulate the affairs of the corporation's business to enhance the formation of shareholders' value through management of the corporation, whereas taking into account the other stakeholders' interest (Hasan \& Butt, 2009). According to report from the Finance Committee on Corporate Governance (1999, p.10), corporate governance is well-defined as:

“... the process and structure used to direct and manage the business and affairs of the company towards enhancing business prosperity and corporate accountability with the ultimate objective of realizing long-term shareholder value...".

Obviously, good corporate governance produces investor confidence and goodwill. Gompers, Ishii and Metrick (2003) stated that valuations are increased and bottom line is enhanced by the good corporate governance. It looks that based on the investor's and lender's trust is upon the corporate governance principles. Good corporate governance practices possibly will have substantial impact on company's strategic decisions such as external financing, which are taken at board level and clearly board of directors is the significant element of the corporate governance. Consequently, board of director's features such as $\mathrm{CEO} /$ Chair duality, presence of non-executive directors, board size and presence of independent directors may have direct influence on the firm's capital structure decisions.

This research paper sheds some lights on the association between some boards of director's facets and capital structure decisions of leading Malaysian firms which are listed on the KLSE (Kuala Lumpur Stock Exchange) for four years from 2005 until the end of 2008.

\subsection{Research Problem}

Corporate governance has been a developing realm of management exploration. There are several reasons for raising the significance of this area such as the 1997- 1998 Asian Financial Crisis, growth of the privatization in past two decades, the progress of private savings, the integration of capital markets, the wave of takeover and the series of corporate scandals such as Enron (Becht, Bolton \& Roell, 2003). According to Claessens, Djankov, Fan and Lang (2002), the consequences of weak corporate governance are not just the poor performance and risky financing patterns; it also leads to macroeconomic crisis. The efficiency of good corporate governance in Asian economies became a very important issue following the 1997-1998 East Asian financial crises. This financial disaster was initiated in Thailand and the harms then moved to nearby countries such as Malaysia and the Philippines. Efforts to cover additional depreciation in Malaysia resulted in greater level of interest rate and credit reduction. This caused a substantial fall of equity prices and subsequently, the severe reductions in corporate profitability. Therefore, Malaysian Institute of Corporate Governance and High Level Finance Committee were created in 1998 in order to educate and generate a good level of awareness about the practices of corporate governance among community, investors and corporate division. This led to announcement of Malaysian code on corporate governance in March 2000.

Malaysia is an emerging market in South-East Asia and one of the rapidly developing economies that has shown a notable performance. Moreover, its stock market has experienced very remarkable presentation. This situation has appealed considerable direct foreign investments to this country. Businesses in this country are being forced to apply the most technical and precise methods in order to compete in the global market. It looks that the base of investor's and lender's confidence is upon the corporate governance principles. Good corporate governance practices possibly will have generous impact on company's strategic decisions such as external financing that are taken at board level which is the crucial element of the corporate governance. Therefore, nowadays, emerging markets especially Malaysia which is one of the rapidly developing economies embraces the concept of good corporate governance due to its capability to influence on sustainable growth.

Obviously, Malaysian companies need to maintain and grow in the global market and attract more foreign companies as a shareholder or partnership. One of the important issues that they have to care about is capital structure of the firm because of its capability to change the cost of capital and expected earnings of the company and subsequently affect the firm's value. The impact of leverage on residual earnings of shareholders is irrefutable. Hence, it is very crucial for Malaysian companies to be aware of the issues regarding the corporate financial policy. 
According to the above discussion, firm's corporate governance or more precisely firm's board of directors which is the significant element of corporate governance and firm's financial policy are two areas that are very important for foreign investors to analyze the company. The existence of agency problems and tendency of managers to execute in their own best interest shows the necessity of presence of an independent board to mitigate these agency problems. Therefore, linkage between the firm's board of directors and capital structure could be very crucial and interesting. The previous studies in case of capital structure are mostly based on traditional determinants of capital structure such as size and growth. We can obviously observe that there are not many researches in developed and developing countries about the association between the corporation's board of directors and leverage of the firm. The shortage and need of this study in emerging markets including Malaysia which is the quickly developing economy is more observable due to necessity of sustainable growth and maintain in global market.

This study tries to bridge the research gap through investigating the association between the board of director's features and capital structure decisions of leading Malaysian firms. The result of this study could be very vital and helpful for sustainability of Malaysian firms in global market. As a result, the research question is:

Is there any significant association between the board of directors and capital structure decision of leading Malaysian firms?

\subsection{Research objectives}

1). To find out the association between the board size and capital structure decisions of leading Malaysian firms.

2). To explore the association between the $\mathrm{CEO} /$ chairman duality and capital structure decisions of leading Malaysian firms.

3). To determine the linkage between the proportion of non-executive directors on the board and capital structure decisions of leading Malaysian firms.

4). To realize the association between the proportions of independent directors on the board and capital structure decisions of leading Malaysian firms.

5). To investigate the contribution of each independent variable to capitalization of decisions prepared by managers.

\section{Capital structure of Malaysian listed companies}

Fan, Titman and Twite (2006) in their study of capital structure among 39 developed and developing countries found developing economies have the higher range of leverage ratio than developed economies with the median leverage of 0.32 and 0.27 respectively. According to their study, Malaysia has a low leverage ratio in comparison with other developing and developed countries. The median leverage ratio for this country is 0.23 which puts Malaysia at the end of the figure just before South Africa and Turkey as developing economies and a few developed countries. On the other hand, in comparison with other Pacific Rim countries, Malaysia only stands before Australia. Moreover, in the case of long term debt ratio, Malaysia stands among the five countries at the end of the leverage spectrum with the median of 0.28 that is lower than the median long-term debt ratio for developing economies in the sample which is 0.35 . De Jong, Kabir and Nguyen (2008) in the study of capital structure all over the world including 42 countries, observed a very low leverage in some emerging markets including Malaysia which is compatible with the result of Fan et al. Booth, Aivazian, Demirguc Kunt and Maksimovic (2001) in their study of capital structure among 10 developing countries put Malaysia in a low-debt group along with Brazil, Mexico and Zimbabwe.

Deesomsak, Paudyal and Pescetto (2004) in their study of capital structure determinants of four Asia pacific countries including Australia, Malaysia, Singapore and Thailand before and after financial crisis found that Malaysia stands between Thailand and Australia in the case of leverage which is also discovered by Fan et al (2006). However, they stated that in Malaysia, the rise in the leverage ratio over the period was higher because of the greater creditor protection compared to other countries. It is also illustrated that the average leverage ratios in Malaysia has risen significantly following the 1997-1998 Asian financial crisis because companies suffered from the losses and market capitalization had fallen.

Based on studies by Pandey (2001), Booth et al (2001), Deesomsak et al (2004), Fraser (2006) and Fan et al (2006), we can conclude that firm-specific factors, legal system, financial and institutional environment, country's public policies and political patronage have an impact on Malaysian public listed companies' capital structure. 


\subsection{Corporate governance definition}

Corporate governance has been well-defined by numerous writers. The Cadbury Committee (1992) described it as "the system by which companies are directed and controlled". Metrick and Ishii (2002) determined it from the viewpoint of investors as "both the promise to repay a fair return on capital invested and the commitment to operate a firm efficiently given (that) investment". This description shows that the character of corporate governance has effects on company's capability to reach capital markets. Aguilera and Jackson (2003) stated that corporate governance is referring to the distribution of privileges and accountabilities amongst numerous performers who are involved in the corporate organization. According to Finance Committee Report on Corporate Governance (1999, p.10), corporate governance is defined as:

"Corporate governance is the process and structure used to direct and manage the business and affairs of the company towards enhancing business prosperity and corporate accountability with the ultimate objective of realizing long-term shareholder value, whilst taking account the interests of other stakeholders".

Based on this definition, the target of corporate governance is not just the shareholders and it also covers all the company's stakeholders.

2.1.1 Corporate governance compliance in the case of board of directors among Malaysian listed companies

Mohamad Ishak, Hartini and Noriza (2004) in their investigation of 556 companies' annual reports publicly registered in Bursa Malaysia in 2002, found that the high level of corporate governance compliance to the Malaysian code best practices for all practices regarding the board of directors including board composition, board meetings, board committees, board remuneration and board responsibilities such as separation the role of board chairman and CEO (Chief Executive Officer). Klapper and Love (2004) in the study among 14 emerging economies discovered the mean rank of Malaysia in the firm level corporate governance index is (54.44). This mean score caused Malaysia to be placed after Brazil, Hong Kong, Chile, Singapore and South Africa. Accordingly Malaysia performed well compared to other countries in the Pacific Rim because it stands after Singapore and Hong Kong with the mean scores of (65.34) and (58.27) respectively. In fact, these countries are more settled and advanced in the case of economic development compared to Malaysia.

Saad (2010) stated that Bursa Malaysia public-listed companies are mostly complied with the Malaysian code best practices. His study was conducted during three periods including pre-implementation of corporate governance (pre-ICG) from 1998 until 2000, mid-implementation of corporate governance (mid-ICG) from 2001 until 2003 and post implementation of corporate governance (post-ICG) from 2004 to 2006. In the case of $\mathrm{CEO} /$ chair duality, he concluded that most of the publicly registered corporations in Malaysia distinct the role of board chairman and CEO. The outcome of his investigation showed that around $70 \%$ of surveyed corporations during the pre-ICG (1998-2000) and around 80\% during the mid-ICG (2001-2003) and post-ICG (2004-2006) separated these two roles. Therefore, before the implementation of Malaysian code to the companies which are publicly registered on the KLSE, the companies' board of directors has already separated the role of board chairman and CEO as also stated in the surveys done by Kuala Lumpur Stock Exchange and PricewaterhouseCoopers (1999) and Abdullah (2001). These surveys denoted that most of the surveyed companies around $70 \%$ had separated the two roles from each other. Saad (2010) also stated that companies that implement the $\mathrm{CEO} / \mathrm{Chair}$ duality in their system have publicly explained the reason in their annual reports which has been compiled with the Malaysian code recommendation. He also found that during mid-ICG, $56.3 \%$ of the companies and post-ICG, $79.5 \%$ of companies allocated 6 to 10 directors in their boards to lead the company. The result of his study is compatible with the Lipton and Lorcsh (1992) that they claimed that the ideal size of the board is 8 to 10 in order to be efficient.

\subsubsection{Corporate governance in Malaysia and implementation of Malaysian Code on corporate governance}

The 1997-1998 Asian financial crises considerably altered the perspective of corporate governance in numerous downfallen countries such as Malaysia. So as to increase the awareness toward corporate governance issues, the High Level Finance Committee on corporate governance and the Malaysian Institute of Corporate Governance were formed in 1998. Accordingly, in March 2000 the Malaysian Code on Corporate Governance was released by the Working Group on Best Practices in Corporate Governance (JPK1) which included combination of public and private sector participation and then it was accepted by the High Level Finance Committee. The code was subsequently revised in 2007. Afterwards, in year 2001, the Malaysian code on corporate governance became an essential part of the Kuala Lumpur Stock Exchange (KLSE) listing rules.

The aim of the code basically is setting out the best practices and principles related to the procedures and structures that corporations possibly implement in their operations to achieve the ideal corporate governance 
structure. The Code is derived from the United Kingdom's (UK) Hamper Report. There are three recommendations that have been set out by the code including corporate governance principles, corporate governance best practices and exhortations to other participants.

Bursa Malaysia through its revamped listing requirements and Malaysian code through its principles and practices, attempt to normalize corporations with the purpose of being more apparent and responsible in their activities to enhance the investors' trust towards the company's activities. Therefore, it is anticipated that this would decrease the agency problems and pave the way for having further effective capital market. Table 1 shows a brief summary towards the Malaysian corporate governance development.

\subsection{Board Size and Capital Structure}

Regarding the discussed literature, there are mixed results concerning the connection between the company's capital structure and size of the board. For instance, Berger et al (1997) and Hasan and Butt (2009) found a negative association and Jensen (1986) and Abor (2007) discovered a positive linkage between the company's gearing level and the board size. If it is assumed that larger quantity of directors on the board puts force on managers to trace lower amount of debt to raise firm's performance, then we suggest that:

H1: There is a significant negative association between the size of the board and company's capital structure.

\subsection{Board Composition and Capital Structure}

Every company's board should consist of external directors (non-executive directors) which mostly comprise of independent non-executives, along with internal directors (executive directors). The necessity of having independent non-executive directors has been indicated in the Malaysian code frequently. The previous studies in the case of external directors and capital structure decisions mostly did not mention that these directors are independent or likewise. They just used a general term such as non-executive directors, outside directors or external directors. In this study, these two elements, non-executive directors and independent directors have been separated and the impressions of both on the capital structure decisions of leading Malaysian firms have been examined. According to the discussed literature the linkage between the existence of external directors and capital structure of the firms is mostly positive. Therefore, we assume that the higher amount of outside directors on the board who are mostly independent reflects that the company is being monitored effectively and subsequently, it is more credit worthy in the view of lenders. So raising the debt financing would be easier for the companies, and hence, we propose that:

H2: There is a significant positive association between the presence of non-executive directors on the board and firm's capital structure.

H3: There is a significant positive linkage between the presence of independent directors on the board and firm's capital structure.

\subsection{CEO/Chairman Duality and Capital Structure}

According to the literature review, there are inconsistent results toward the connection between the $\mathrm{CEO} / \mathrm{Chair}$ duality and company's capital structure. For instance, Kyereboah-Coleman and Biekpe (2006) and Fosberg (2004) discovered a negative association but Abor (2007) and Abor and Biekpe (2006) found a positive linkage between the $\mathrm{CEO} /$ Chair duality and company's capital structure. If we assume that holding the board chair empowers CEOs to apply more control over board decisions and subsequently lessening its monitoring role to control the optimal level of debt taken by the management, we can propose that:

H4: There is a considerable negative association between the CEO/Chair duality and company's capital structure.

Based on the literature review above, the research framework and the research variables are operationalised (see Figure 1 and Table 2).

\section{Method}

\subsection{Data Collection}

The data for this investigation is derived from secondary data which was extracted from the Leading Malaysian companies' annual reports publicly registered on the KLSE from 2005-2008 fiscal years. Companies' annual reports are sufficient for gathering the related information on board of directors' features. Emerging markets information service (EMIS) website which is a product of ISI emerging markets along with company's annual financial reports that are available on the official website of Bursa Malaysia have been used to extract the data 
concerning the firm's capital structure. The official web site of the Bursa Malaysia (www.bursamalaysia.com) and the EMIS website (www.securities.com) have been used to access to the above-mentioned information.

\subsection{Sample selection}

This study's target is about exploring the linkage between board of director's features and capital structure of 100 non-financial leading Malaysian companies, which are employed as a price index and listed on the KLSE from 2005 to 2008. Financial organizations are excluded since they are administrated by special rules. In order to ensure about the consistency of data, only companies providing accessible and valid information for the relevant period have been considered here. Also all the companies in the sample should fulfill these two criteria: they are all listed in the market in 2005 and none of them was excluded during the period 2005-2008. The sample size after considering these criteria consists of 75 leading firms that are publicly listed on the KLSE.

\section{Results and Findings}

\subsection{Descriptive statistics}

Table 3 offers a brief descriptive information summary associated with the independent and dependent variables for the average of four years from 2005-2008. According to the above table, there are 75 leading companies which provided acceptable relevant data for these years. The debt ratio (DR) of these companies is distributed with the mean (median) of .443880 (.464056) and Standard deviation of .1608202. This shows that the average $44.4 \%$ of leading Malaysian companies' total assets are financed by debt capital through these four years. The board size (BS) is distributed with the mean (median) of .927959 (.941454) and standard deviation of .1089717. Non-executive directors (NED) are distributed with the mean (median) of .708136 (.732143) and standard deviation of .1533460 and independent non-executive directors (INED) are distributed with the mean (median) of .420030 (.406250) and standard deviation of .0886101 respectively. CEO's duality (CD) has the mean (median) of .073333 (.000000) and standard deviation of .2458209. This suggests that leading Malaysian companies with the CEO serving as a chairperson constitute $7.3 \%$ throughout these four years on average number. In most of leading Malaysian companies, CEO and chairperson are two different individuals who have been emphasized in the Malaysian code on corporate governance.

\subsection{Correlation}

According to Table 4, all independent variables have a correlation of less than .7; consequently, all variables are being considered for regression analysis. Based on the Table 4, BS, NED and CD have a negative correlation with DR and the variable of INED directors has a positive correlation with DR. based on the significance of the relationships, variables BS and INED have a significant correlation with DR due to their p-values, .002 and .001, which are less than .05 and variables NED and CD do not have a significant correlation with DR since their high p-values, .825 and .201 , which are more than .05 throughout 2005-2008 respectively.

\subsection{Regression Result}

Table 5 displays the regression analysis summary for the average of four years throughout 2005-2008. The R Square is .208 that indicates, $20.8 \%$ of the alteration in debt ratio could be described by the alteration in independent variables including BS, NED, INED and CD. From Table 6, the p-value is .002 lower than 0.05. This specifies that minimum one of the four independent variables including the BS, NED, INED and CD could be implemented to estimate the dependent variable which is the debt ratio from 2005 until 2008 averagely. According to Table 7, the p-values for the independent variables including BS and INED are .048 and .025 respectively which are lower than 0.05 . This demonstrates that in 95 percent of confidence level, there is a substantial linkage between the DR with BS and INED. On the other hand, the p-values for NED and CD are .228 and .229 respectively which are more than .05 . Therefore, there is no considerable connection between the debt ratio and these two independent variables. The direction of relationship with DR is positive for INED and negative for BS, NED and CD which is well-matched with the Pearson correlation results. According to the coefficients table, the regression equation for the average of the four years from 2005 until 2008 is written as below:

DR (Average 2005-2008) $=.666-.351 . \mathrm{BS}$-.141.NED + .500.INED -.088.CD

The interpretation of this equation is that for every unit rise in BS, DR will drop by .351 units, as long as other independent variables including NED, INED and CD remain unchanged. 


\subsection{Hypothesis Testing}

\subsubsection{Board size and capital structure}

According to Table 7, the p-value for BS is .048, and the Beta value is -.238 . it can be concluded that there is a significant negative association between the size of the board and company's capital structure. Hence, hypothesis 1 is accepted for the average of the 4 years from 2005 until the end of 2008. This outcome is compatible with the result of Berger et al (1997), Abor and Biekpe (2006) and Hasan and Butt (2009).

\subsubsection{Non-executive directors and capital structure}

Table 7 shows that the p-value for NED is .228. Hence, there is no substantial connection between the existence of NEDs on the board and firms capital structure. Consequently, hypothesis 2 is strongly rejected for leading Malaysian companies during 2005-2008 because both p-values which are more than .05 and the beta value which is negative. The possible reason for this position is that outside directors in this country are not mostly comprised of independent directors while in the next hypothesis, we can see the influence of independent directors on the board and firm's capital structure. Bokpin and Arko (2009) and Hasan and Butt (2009) also discovered no significant connection between the presence of outside directors on the board and firm's capital structure.

\subsubsection{Independent non-executive directors and capital structure}

The indicated p-value in Table 7 concerning the INED is 0.025 , and the beta value is .275 respectively. Consequently, there is a significant positive linkage between the number of independent non-executive directors on the board and firm's capital structure. Hence, hypothesis 3 is accepted.

\subsubsection{CEO/Chair duality and capital structure}

According to Table 7, the p-value for CEO/Chair duality is .229 , and the beta value is -.134 respectively. Therefore, there is no substantial connection between the CEO/Chair duality and company's capital structure. Based on the p-value and beta value results, hypothesis 4 is rejected. In general, around $90 \%$ of leading Malaysian companies have separated the role of CEO and chairman and possibly this is the reason that the CEO/Chair duality has no significant effect on company's capital structure. Hasan and Butt (2009) also found no significant connection between the CEO/Chair duality and firm's capital structure.

\section{Discussion}

This study examines the linkage between board of directors and company's capital structure for 75 non-financial leading Malaysian companies, which are employed as a price index, listed on Kuala Lumpur Stock Exchange (KLSE) from 2005 to 2008 fiscal years via multiple regression analysis. The board of director's features used for this research comprised of board size, $\mathrm{CEO} /$ Chair duality and board composition including outside directors and independent directors. According to the year by year analysis from 2005 to 2008 and average analysis for these four years, the empirical results demonstrate statistically significant negative association between capital structure and size of the board and statistically significant positive relationship between capital structure and the existence of independent directors on the board respectively.

On the other hand, empirical results show no significant linkage between the capital structure and existence of outside directors on the board and CEO/Chair Duality. Only in 2005, CEO/chair duality showed a significant negative association with capital structure. The possible reason for the insignificant association between the company's capital structure and NEDs is that non-executive directors in Malaysia are not mostly comprised of independent directors while based on the empirical results, companies followed higher debt policy with a greater percentage of independent directors on the board. However, based on correlation results, the existence of outside directors on the board and $\mathrm{CEO} /$ Chair duality are negatively correlated with the firm's capital structure. This insignificant negative relationship of NEDS with the firm's capital structure points out that the higher number of NEDs on the board, who are not mostly independent, does not have an effective supervision over the managers in order to force them to select the optimal level of debt. Moreover, it also could lead to the employment of the lower level of debt which is probably not appropriate for the shareholder's interest. Based on the collected data concerning the $\mathrm{CEO} / \mathrm{Chair}$ duality, around $90 \%$ of leading Malaysian companies have distinctive roles of Chief Executive Officer and Chairman which is consistent with the Malaysian code on corporate governance's recommendation. Possibly, this could be the reason that the $\mathrm{CEO} /$ Chair duality has no significant effect on leading Malaysian firm's capital structure.

In general, the average analysis from 2005 to 2008 indicates that Malaysian leading companies followed lower debt policy with larger board size and pursued higher debt policy with the higher percentage of independent 
directors on the board. Therefore, hypothesis 1 and hypothesis 3 are consistent with the condition of leading Malaysian companies.

\section{Conclusion}

While the purpose of this study is exploring the relationship among board structure and capital structure decision in Malaysia, the results and evidences indicate that there are not enough proofs to prove companies with good corporate governance perform better than companies which are not respect to it that much.

One important implication for this study is that it can be a guideline for companies' owners and managers to find their level of commitment to the corporate governance in Malaysia. By this way they can help government to find the weaknesses and strengths, as well as improve the corporate governance practices which is completely match with Malaysian culture, economy, politics. Therefore, a good corporate governance mechanism is also predicted to reduce corporate issues via efficient controlling of an independent board which is motivating managers to perform in the shareholders' best interest thus enhance the firm's value.

Malaysia as an emerging market in South-East Asia, and one of the rapidly developing economies, is hoping to attract more foreign direct investment from year to year. The more companies respect to the corporate governance, the more they can expect the investors trust them and select them as a secure company for investing purpose. Companies must considered this fact that research such as present one to give a transparent face of them in public and more people tend to invest in this type of companies.

\section{Limitations and recommendations for future research}

The target of this research paper is to explore the linkage between the board of directors and company's capital structure among leading Malaysian companies and it did not cover the entire market. Hence, the result may not represent the population of Malaysian companies. This is because of the nature of the research which depends on the time and the availability of required data. So another study with a greater number of Malaysian companies in different sectors is highly recommended.

Moreover, in this study, only four variables have been examined to explore the linkage between board of directors and capital structure of the leading Malaysian companies. The reason is that the accessibility to the board of directors' information relies on the extent of companies' transparency in their annual reports. Some variables including CEO's tenure and CEO's compensation are omitted due to companies' unwillingness to disclose such information. Expanding the number of variables concerning the board of directors and corporate governance including number of board meetings, CEO's compensation, CEO's tenure, board skills and institutional shareholding are recommended for future research.

\section{References}

Abdullah, S. N. (2001). Characteristics of board of directors and audit committees among Malaysian listed companies in period leading to 1997 financial crisis. Accountant National, 14(10), 18-20.

Abdullah, S. N. (2004). Board composition, CEO duality and performance among Malaysian listed companies. Corporate Governance, 4(4), 47-61. http://dx.doi.org/10.1108/14720700410558871

Abor, J. \& Biekpe, N. (2005). What determines the capital structure of listed firms in Ghana? The African Finance Journal, 7(1), 37-48.

Abor, J. \& Biekpe, N. (2006). Does Corporate Governance Affect the Capital Structure Decisions of Ghanaian SMEs? Corporate Ownership \& Control, 1, 113-118.

Abor, J. (2007). Corporate governance and financing decisions of Ghanaian listed firms. Corporate Governance, 7(1), 83-92. http://dx.doi.org/10.1108/14720700710727131

Adams, R. \& Mehran, H. (2008). Corporate performance, board structure and its determinants in the banking industry. Federal Reserve Bank of New York Working Paper.

Aguilera, R. V. \& Jackson, G. (2003). The cross-national diversity of corporate governance: Dimensions and determinants. Academy of Management Review, 28(3), 447-465.

Al-Nodel, A. \& Hussainey, K. (2010). Corporate governance and financing decisions by Saudi companies. Journal of Modern Accounting and Auditing, 6(8), 1-14.

Anderson, R. C., Mansi, S. A. \& Reeb, D. M. (2004). Board characteristics, accounting report integrity, and the cost of debt. Journal of Accounting and Economics, 37(3), 315-342. http://dx.doi.org/10.1016/j.jacceco.2004.01.004 
Becht, M., Bolton, P. \& Röell, A. (2003). Corporate governance and control. Handbook of the Economics of Finance, 1, 1-109. http://dx.doi.org/10.1016/S1574-0102(03)01005-7

Berger, P. G., Ofek, E. \& Yermack, D. L. (1997). Managerial entrenchment and capital structure decisions. The Journal of Finance, 52(4), 1411-1438. http://dx.doi.org/10.2307/2329441

Bokpin, G. A. \& Arko, A. C. (2009). Ownership structure, corporate governance and capital structure decisions of firms: Empirical evidence from Ghana. Studies in Economics and Finance, 26(4), 246-256. http://dx.doi.org/10.1108/10867370910995708

Booth, L., Aivazian, V., Demirguc Kunt, A. \& Maksimovic, V. (2001). Capital structures in developing countries. The Journal of Finance, 56(1), 87-130. http://dx.doi.org/10.1111/0022-1082.00320

Bunkanwanicha, P., Gupta, J. \& Rokhim, R. (2008). Debt and entrenchment: Evidence from Thailand and Indonesia. European Journal of Operational Research, 185(3), 1578-1595. http://dx.doi.org/10.1016/j.ejor.2006.08.025

Bursa Malaysia Revamped Listing Requirements. (2001). [Online] Available: www.bursamalaysia.com Cadbury, A. (1992). Committee on the financial aspects of corporate governance. Gee and Co Publishing Ltd. Chaganti, R. S., Mahajan, V. \& Sharma, S. (1985). Corporate board size, composition and corporate failures in retailing industry. Journal of Management Studies, 22(4), 400-417. http://dx.doi.org/10.1111/j.1467-6486.1985.tb00005.x

Claessens, S., Djankov, S., Fan, J. P. H. \& Lang, L. H. P. (2002). Disentangling the incentive and entrenchment effects of large shareholdings. Journal of finance, 57(6), 2741-2771. http://dx.doi.org/10.1111/1540-6261.00511

Dalton, C. M. \& Dalton, D. R. (2005). Boards of directors: Utilizing empirical evidence in developing practical prescriptions. British Journal of Management, 16, 91-97. http://dx.doi.org/10.1111/j.1467-8551.2005.00450.x

Dalton, D. R., Daily, C. M., Ellstrand, A. E. \& Johnson, J. L. (1998). Meta analytic reviews of board composition, leadership structure, and financial performance. Strategic Management Journal, 19(3), 269-290. http://dx.doi.org/10.1002/(SICI)1097-0266(199803)19:3<269::AID-SMJ950>3.0.CO;2-K

De Jong, A., Kabir, R. \& Nguyen, T. T. (2008). Capital structure around the world: The roles of firm-and country-specific determinants. Journal of Banking \& Finance, 32(9), 1954-1969. http://dx.doi.org/10.1016/j.jbankfin.2007.12.034

Deesomsak, R., Paudyal, K. \& Pescetto, G. (2004). The determinants of capital structure: evidence from the Asia Pacific region. Journal of Multinational Financial Management, 14(4-5), 387-405. http://dx.doi.org/10.1016/j.mulfin.2004.03.001

Fama, E. F. \& Jensen, M. C. (1983). Separation of ownership and control. Journal of Law and Economics, 26(2), 301-325. http://dx.doi.org/10.1086/467037

Fan, J. P. H., Titman, S. \& Twite, G. (2006). An International Comparison of Capital Structure and Debt Maturity Choices. Chinese University of Hong Kong and University of Texas in Austin Working Paper.

Finance Committee on Corporate Governance (FCCG). (2000). Malaysian Code on Corporate Governance 2000. Kuala Lumpur: Ministry of Finance, Malaysia.

Finance Committee on Corporate Governance (FCCG). (2007). Malaysian Code on Corporate Governance revised 2007. Kuala Lumpur: Ministry of Finance, Malaysia.

Fosberg, R. H. (2004). Agency problems and debt financing: leadership structure effects. Corporate Governance, 4(1), 31-38. http://dx.doi.org/10.1108/14720700410521943

Fraser, D. R., Zhang, H. \& Derashid, C. (2006). Capital structure and political patronage: The case of Malaysia. Journal of Banking \& Finance, 30(4), 1291-1308. http://dx.doi.org/10.1016/j.jbankfin.2005.05.008

Gompers, P., Ishii, J. \& Metrick, A. (2003). Corporate governance and equity prices. Quarterly Journal of Economics, 118(1), 107-155. http://dx.doi.org/10.1162/00335530360535162

Haniffa, R. M. \& Cooke, T. E. (2002). Culture, corporate governance and disclosure in Malaysian corporations. A Journal of Accounting, Finance and Business Studies, 38(3), 317-349.

Hasan, A. \& Butt, S. A. (2009). Impact of ownership structure and corporate governance on capital structure of Pakistani listed companies. International Journal of Business \& Management, 4(2), 50-57. 
Hermalin, B. \& Weisbach, M. (2000). Boards of directors as an endogenously determined institution: a survey of the economic literature. Berkeley and University of Illinois Working Paper.

Jensen, M. C. \& Meckling, W. H. (1976). Theory of the firm: Managerial behavior, agency costs and ownership structure. Journal of Financial Economics, 3(4), 305-360. http://dx.doi.org/10.1016/0304-405X(76)90026-X

Jensen, M. C. (1986). Agency costs of free cash flow, corporate finance, and takeovers. The American Economic Review, 76(2), 323-329.

Jensen, M. C. (1993). The modern industrial revolution, exit, and the failure of internal control systems. Journal of Finance, 48, 831-880. http://dx.doi.org/10.2307/2329018

Klapper, L. F. \& Love, I. (2004). Corporate governance, investor protection, and performance in emerging markets. Journal of Corporate Finance, 10(5), 703-728. http://dx.doi.org/10.1016/S0929-1199(03)00046-4

Kosnik, R. D. (1987). Greenmail: A study of board performance in corporate governance. Administrative Science Quarterly, 32(2), 163-185. http://dx.doi.org/10.2307/2393124

Kuala Lumpur Stock Exchange \& Pricewaterhouse Coopers. (1999). Corporate governance: 1998 survey of public listed companies.

Kyereboah coleman, A. \& Biekpe, N. (2006). Corporate governance and financing choices of firms: a panel data analysis. South African Journal of Economics, 74(4), 670-681.

Lee, K. W. \& Yeo, G. H. H. (2010). Capital Structure in Asia and CEO Entrenchment. Handbook of Quantitative Finance and Risk Management, 863-872.

Lee, L. S. (2002). Independent directors, their role and effectiveness in the board. The Malaysian Corporate Secretary, 14, 12-19.

Lipton, M. \& Lorsch, J. W. (1992). Modest Proposal for Improved Corporate Governance. The Business Lawyer, 48, 59-77.

Litov, L. (2005). Corporate governance and financing policy: new evidence. New York University Working Paper.

Lundstrum, L. L. (2009). Entrenched management, capital structure changes and firm value. Journal of Economics and Finance, 33(2), 161-175. http://dx.doi.org/10.1007/s12197-008-9037-3

Mace, M.L. (1971). Directors: Myth and Reality. Harvard Business School Press, Boston.

Mak, Y. T. \& Li, Y. (2001). Determinants of corporate ownership and board structure: evidence from Singapore. Journal of Corporate Finance, 7(3), 235-256. http://dx.doi.org/10.1016/S0929-1199(01)00021-9

Mallette, P. \& Fowler, K. L. (1992). Effects of board composition and stock ownership on the adoption of poison pills. The Academy of Management Journal, 35(5), 1010-1035. http://dx.doi.org/10.2307/256538

Mashayekhi, B. \& Bazaz, M. S. (2008). Corporate governance and firm performance in Iran. Journal of Contemporary Accounting \& Economics, 4(2), 156-172.

Metrick, A. \& J. Ishii. (2002). Firm-level corporate governance. Global Corporate Governance Forum, Research Network.

Modigliani, F. \& Miller, M. H. (1958). The cost of capital, corporation finance and the theory of investment. The American Economic Review, 48(3), 261-297.

Modigliani, F. \& Miller, M. H. (1963). Corporate income taxes and the cost of capital: A correction. The American Economic Review, 53(3), 433-443.

Mohamad Ishak M.I., Hartini J. \& Noriza M.S. (2004). The Disclosure of Corporate Compliance Program: A Study on the Board of Directors in the Bursa Malaysia Public-Listed Companies. Paper presented at the UIBMC.

Myers, S. C. \& Majluf, N. S. (1984). Corporate financing and investment decisions when firms have information that investors do not have. Journal of Financial Economics, 13(2), 187-221. http://dx.doi.org/10.1016/0304-405X(84)90023-0

Myers, S. C. (1977). Determinants of corporate borrowing. Journal of Financial Economics, 5(2), 147-175. http://dx.doi.org/10.1016/0304-405X(77)90015-0

Myers, S. C. (2003). Financing of corporations. Handbook of the Economics of Finance, 1, 215-253. http://dx.doi.org/10.1016/S1574-0102(03)01008-2 
Narasimhan, K. (2002). Are Bigger Boards Less Efficient? Evidence from investment and debt policies during the 'Great Depression'. Fuqua School of Business Seminar.

Othman, R., Ponirin, H. \& Ghani, E. K. (2009). The effect of board structure on shareholders' wealth in small listed companies in Malaysia. Management Science and Engineering, 3(4), 1-15.

Pandey, I. M. (2001). Capital structure and the firm characteristics: evidence from an emerging market. Indian Institute of Management Ahmedabad Working Paper.

Pfeffer, J. \& Salancik, G.R. (1978). The External Control of Organizations: A Resource-Dependence Perspective. New York: Harper \& Row.

Pi, L. \& Timme, S. G. (1993). Corporate control and bank efficiency. Journal of Banking \& Finance, 17(2-3), 515-530. http://dx.doi.org/10.1016/0378-4266(93)90050-N

Rahman, R. A. \& Ali, F. H. M. (2006). Board, audit committee, culture and earnings management: Malaysian evidence. Managerial Auditing Journal, 21(7), 783-804. http://dx.doi.org/10.1108/02686900610680549

Rechner, P. L. \& Dalton, D. R. (1991). CEO duality and organizational performance: A longitudinal analysis. Strategic Management Journal, 12(2), 155-160. http://dx.doi.org/10.1002/smj.4250120206

Rechner, P. L. (1989). Corporate governance: fact or fiction? Business Horizons, 32(4), 11-15. http://dx.doi.org/10.1016/0007-6813(89)90051-7

Ross, S. A. (1977). The determination of financial structure: the incentive-signalling approach. The Bell Journal of Economics, 8(1), 23-40. http://dx.doi.org/10.2307/3003485

Saad, N. M. (2010). Corporate Governance Compliance and the Effects to Capital Structure in Malaysia. International Journal of Economics and Finance, 2, 105-114.

Singam, K. (2003). Corporate Governance in Malaysia. Bond Law Review, 15 (1), 313-344.

Stulz, R. M. (1988). Managerial control of voting rights: Financing policies and the market for corporate control. Journal of Financial Economics, 20, 25-54. http://dx.doi.org/10.1016/0304-405X(88)90039-6

Vancil, R. F. (1987). Passing the baton: Managing the process of CEO succession. Harvard Business School Press, Boston.

Weir, C. \& Laing, D. (2001). Governance structures, director independence and corporate performance in the UK. European Business Review, 13(2), 86-95. http://dx.doi.org/10.1108/09555340110385254

Wen, Y., Rwegasira, K. \& Bilderbeek, J. (2002). Corporate governance and capital structure decisions of the Chinese listed firms. Corporate Governance: An International Review, 10(2), 75-83. http://dx.doi.org/10.1111/1467-8683.00271 
Table 1. Development of Malaysian Corporate Governance Development

\begin{tabular}{|l|l|}
\hline \multicolumn{1}{|c|}{ Types of Corporate Governance Practices } & \multicolumn{1}{c|}{ Overview } \\
\hline Malaysian code on governance practices & $\begin{array}{l}\text { Originated with the formation of finance committee } \\
\text { in 1998 which had been the result in releasing the } \\
\text { Malaysian code in March 2000 and became an } \\
\text { essential part of KLSE in 2001. It consisted of } \\
\text { principles and best practices towards corporate } \\
\text { governance in Malaysia. }\end{array}$ \\
\hline Capital Market Master Plan (CMP) & $\begin{array}{l}\text { Originally announced in 1999, accepted by Finance } \\
\text { Minister in 2000 and was finally launched in 2001. } \\
\text { Effectual allocation of funds along with high level } \\
\text { of certainty to market participants is CMP visions } \\
\text { framework. A principal strategic thrust of the } \\
\text { Capital Market Master Plan is corporate } \\
\text { governance. }\end{array}$ \\
\hline Financial Sector Master Plan (FSMP) & $\begin{array}{l}\text { Firstly launched in 2001 through the Bank Negara } \\
\text { Malaysia in order to plan the upcoming direction of } \\
\text { the financial sector. Elevating consumers' and } \\
\text { shareholders' involvements, regulatory control and } \\
\text { priority sector financing are corporate governance } \\
\text { elements that have been suggested by the FSMP. }\end{array}$ \\
\hline Institutional Development & $\begin{array}{l}\text { Corporate governance development in Malaysia is } \\
\text { complemented through the institutional } \\
\text { development. }\end{array}$ \\
\hline
\end{tabular}

Table 2. Operationalisation of Research Variables

\begin{tabular}{|c|c|c|}
\hline \multicolumn{2}{|c|}{$\begin{array}{c}\text { Independent variables and Dimensions } \\
\text { References }\end{array}$} & $\begin{array}{c}\text { Dependent variables and Dimensions } \\
\text { References }\end{array}$ \\
\hline Board size & $\begin{array}{c}\text { Wen et al (2002) and Hasan and Butt } \\
\text { (2009) } \\
\text { (logarithm of number of board } \\
\text { members) }\end{array}$ & \multirow{4}{*}{$\begin{array}{c}\text { Firm's Capital Structure } \\
\text { Bunkanwanicha, Gupta and Rokhim (2008), } \\
\text { Wen et al (2002), Fan et al (2006) and } \\
\text { Pandey (2001) } \\
\text { (debt to asset ratio) }\end{array}$} \\
\hline $\begin{array}{c}\text { Presence of } \\
\text { non-executive } \\
\text { directors }\end{array}$ & $\begin{array}{c}\text { Wen et al (2002), Hasan and Butt } \\
\text { (2009) and Kyereboah-Coleman and } \\
\text { Biekpe (2006) } \\
\text { (number of outside directors divided } \\
\text { by the whole number of members on } \\
\text { the board) }\end{array}$ & \\
\hline $\begin{array}{c}\text { Existence of } \\
\text { independent } \\
\text { directors }\end{array}$ & $\begin{array}{c}\text { Wen et al (2002), Hasan and Butt } \\
\text { (2009) and Kyereboah-Coleman and } \\
\text { Biekpe (2006) } \\
\text { (number of independent directors } \\
\text { divided by the whole number of board } \\
\text { members) }\end{array}$ & \\
\hline $\begin{array}{l}\text { CEO/Chair } \\
\text { duality }\end{array}$ & $\begin{array}{c}\text { Dalton et al. (1998), Hafiza (2009), } \\
\text { Barton et al. (2004), and Goodstein et } \\
\text { al. (1994). } \\
\text { (dummy variable, when a CEO takes } \\
\text { charge as a board chairman, the } \\
\text { variable is equal to } 1 \text { and otherwise is } \\
\text { zero) }\end{array}$ & \\
\hline
\end{tabular}


Table 3. Descriptive statistics average for 2005-2008

\begin{tabular}{|c|c|c|c|c|c|c|}
\hline & mean & Median & $\begin{array}{c}\text { Std. } \\
\text { Deviation }\end{array}$ & minimum & maximum & $\mathrm{N}$ \\
\hline DR & .443880 & .464056 & .1608202 & .0954 & .9104 & 75 \\
\hline BS & .927959 & .941454 & .1089717 & .6990 & 1.1536 & 75 \\
\hline NED & .708136 & .732143 & .1533460 & .3077 & 1.0000 & 75 \\
\hline INED & .420030 & .406250 & .0886101 & .2560 & .6500 & 75 \\
\hline CD & .073333 & .000000 & .2458209 & .0000 & 1.0000 & 75 \\
\hline
\end{tabular}

Table 4. Correlation average for 2005-2008

\begin{tabular}{|l|c|c|c|c|c|}
\hline & DR & BS & NED & INED & CD \\
\hline DR Pearson Correlation & 1 & -.344 & -.026 & .373 & -.149 \\
Sig. (2-tailed) & & .002 & .825 & .001 & .201 \\
\hline BS Pearson Correlation & & & & & \\
Sig. (2-tailed) & -.344 & 1 & -.113 & -.431 & .023 \\
\hline NED Pearson Correlation & .002 & & .334 & .000 & .842 \\
Sig. (2-tailed) & -.026 & -.113 & 1 & .185 & -.230 \\
\hline INED Pearson Correlation & .825 & .334 & & .111 & .047 \\
Sig. (2-tailed) & .373 & -.431 & .185 & 1 & -.149 \\
\hline CD Pearson Correlation & .001 & .000 & .111 & & .202 \\
\hline Sig. (2-tailed) & -.149 & .023 & -.230 & -.149 & 1 \\
\hline
\end{tabular}

Table 5. Model summary average for 2005-2008

\begin{tabular}{|c|c|c|c|c|}
\hline Model & R & R Square & $\begin{array}{c}\text { Adiusted R } \\
\text { Square }\end{array}$ & $\begin{array}{c}\text { Std. Error of } \\
\text { the Estimate }\end{array}$ \\
\hline 1 & .456 & .208 & .163 & .1471652 \\
\hline
\end{tabular}


Table 6. ANOVA average for 2005-2008

\begin{tabular}{|cc|c|c|c|c|c|}
\hline \multicolumn{2}{|c|}{} & Sum of & & Mean & \multirow{2}{*}{ F } & Sig \\
\hline 1 & & Squares & & Square & & \\
\hline & Regression & .398 & 4 & .099 & 4.592 & .002 \\
& Residual & 1.516 & 70 & .022 & & \\
& \multicolumn{1}{|c|}{ Total } & 1.914 & 74 & & & \\
\hline
\end{tabular}

Table 7. Coefficients average for 2005-2008

\begin{tabular}{|c|c|c|c|c|c|c|c|}
\hline \multirow{2}{*}{ Model } & \multicolumn{2}{|c|}{$\begin{array}{l}\text { Unstandardized } \\
\text { Coefficients }\end{array}$} & \multirow{2}{*}{$\begin{array}{c}\text { Standardized } \\
\text { Coefficients } \\
\text { Beta }\end{array}$} & \multirow{2}{*}{$\mathrm{t}$} & \multirow{2}{*}{ Sig. } & \multicolumn{2}{|c|}{$\begin{array}{c}\text { Collinearity } \\
\text { Statistics }\end{array}$} \\
\hline & B & Std. Error & & & & Tolerance & VIF \\
\hline 1 (Constant) & .666 & .233 & & 2.863 & .006 & & \\
\hline BS & -.351 & .174 & -.238 & -2.010 & .048 & .810 & 1.234 \\
\hline NED & -.141 & .116 & -.135 & -1.215 & .228 & .921 & 1.085 \\
\hline INED & .500 & .218 & .275 & 2.290 & .025 & .783 & 1.277 \\
\hline $\mathrm{CD}$ & -.088 & .072 & -.134 & -1.215 & .229 & .932 & 1.072 \\
\hline
\end{tabular}

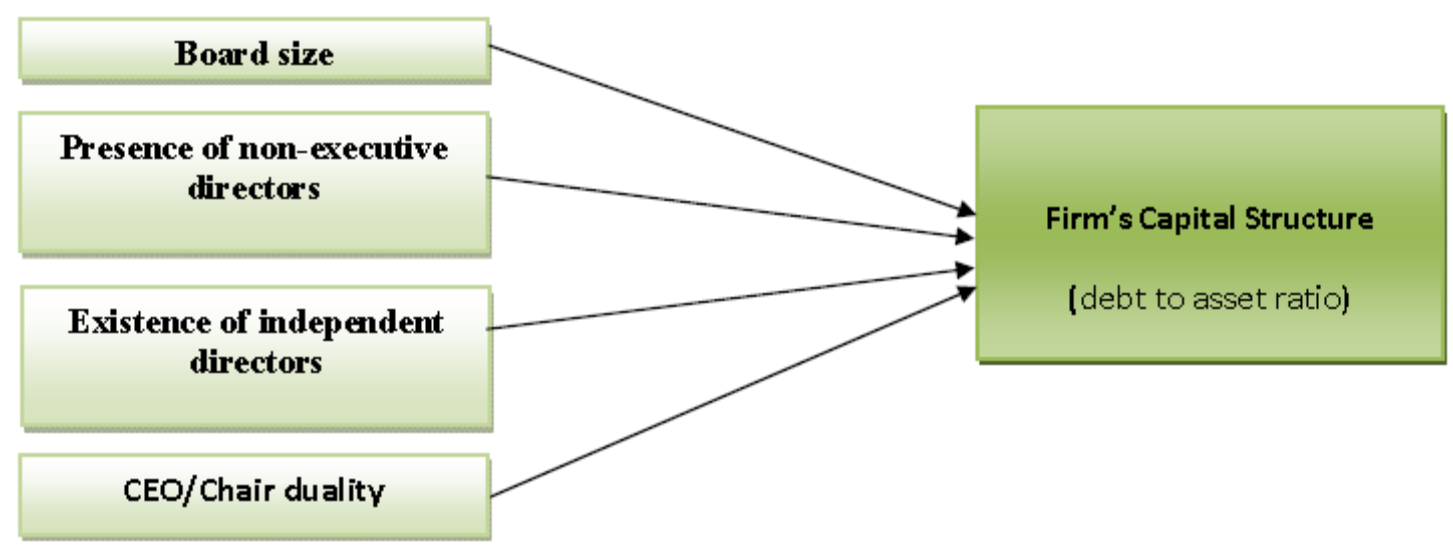

Figure 1. Conceptual framework 